\title{
POVSTANIE PKK/KCK V ROKOCH 2015-2016 V TURECKU
}

Z hôr do mesta a naspät': Priebeh a poučenia z bojov

\section{PKK/KCK INSURGENCY IN TURKEY IN 2015-2016 \\ Out of the mountains to the city and back: Course of the conflict and lessons learned}

Matúš Jevčák ${ }^{a}$

\begin{abstract}
Abstrakt
Text detailne mapuje priebeh povstania PKK/KCK $\vee$ Turecku $\vee$ rokoch 2015-2016. Autor okrem samotného popisu vývoja povstania čitatelovi predkladá detailný obraz bojov v urbánnych oblastiach tureckého juhovýchodu, ktorý predstavoval bezprecedentnú novinku v rámci vyše 30 rokov trvajúceho konfliktu medzi Kurdskou stranou pracujúcich a Tureckom. Zámerom je identifikovat' klúčové charakteristiky a taktické prvky využívané ako PKK/KCK, tak tureckými ozbrojenými zložkami a zároveň vyvodit' možné závery vyplývajúce $z$ tureckých skúseností vedenia ozbrojeného boja v urbánnych oblastiach.
\end{abstract}

\begin{abstract}
The text focuses on the PKK/KCK insurgency in Turkey in 2015-2016. Besides the description of the course of the conflict, the article provides a detailed picture of the urban warfare in southeast Turkey during the selected period. The urban guerrilla campaign of the PKK/KCK was a novelty in the 30-year conflict between the insurgent organization on one side and the Turkish state on the other. The aim is to identify key characteristics and tactical features used by the PKK/KCK and the Turkish security forces respectively. The conclusion of the text brings an analysis of the conflict together with recommendations for urban warfare and the lessons Turkey learned in 2015-2016.
\end{abstract}

\section{Klíčová slova}

PKK/KCK, Turecko; povstanie; protipovstalecký boj; terorizmus; guerrilla; mestská guerrilla.

\section{Keywords}

PKK/KCK; Turkey; counterinsurgency; terrorism; guerrilla; urban guerilla.

\footnotetext{
a Department of Political Science, Faculty of Social Studies, Masaryk University. Brno, Czech Republic. Email: matus.jevcak@gmail.com, AAI-8185-2020.
} 


\section{ÚVOD}

Strana kurdských pracujúcich (PKK) predstavuje pre Tureckú republiku už vyše 30 rokov jednu z najvýznamnejších bezpečnostných hrozieb. Ozbrojený konflikt medzi PKK a Tureckom si od roku 1984 vyžiadal 30000 až 50000 obetí, pričom vyše milióna ludí bolo nútených opustit' svoje domovy. ${ }^{1}$ Hoci dnes PKK nepredstavuje tak masívnu hrozbu ako v 90. rokoch, vývoj v rokoch 2015-2016 ukázal, že sa stále jedná o organizáciu s početnou členskou základňou a širokou škálou schopností.

Za dobu svojej existencie prešla PKK viacerými zmenami. Tie sa odrazili aj v opakovanom premenovávaní organizácie, ktorá bola formálne od roku 2005 začlenená do širšej organizačnej štruktúry nazvanej L'udová konfederácia Kurdistanu (KKK), premenovanej o dva roky neskôr na Zväz komunít Kurdistanu (KCK). Z tohto dôvodu autor používa d'alej $v$ texte skratku PKK/KCK.

Značným vývojom prešiel aj samotný ozbrojený konflikt medzi PKK a Tureckom, v priebehu ktorého sa vystriedali obdobia ozbrojeného násilia s fázami dočasného prímeria. Konflikt vyvrcholil zatknutím Abdullaha Öcalana, zakladatel'a a vodcu PKK, v roku 1999 v Keni po tom, čo musel na nátlak Turecka opustit' Sýriu. Organizácia následne vyhlásila prímerie, ktoré netrvalo dlho, a od roku 2004 obnovila ozbrojený boj, ktorý s prestávkami trval až do roku 2012. Napriek tomu, že vtedajší mierový proces vzbudzoval mnoho očakávaní a vyvolal nádej na ukončenie a vyriešenie dlhoročného konfliktu, nestalo sa tak, a v roku 2015 sa ozbrojené strety medzi PKK a tureckými bezpečnostnými zložkami rozhoreli opät' naplno. $V$ rámci nich organizácia nasadila viacero podriadených zložiek, ktoré sa prezentovali širokou paletou ozbrojených foriem boja, počnúc typickou rurálnou guerillou, terorizmom v mestách, ale aj na pomery PKK/KCK inovatívnym využitím mestskej guerilly.

Ciel'om tejto štúdie je popísat' a analyzovat' priebeh povstania PKK/KCK v rokoch 20152016 práve s dôrazom na boje $v$ mestách a identifikovat' možné závery vyplývajúce $z$ tureckých skúseností vedenia ozbrojeného boja $v$ urbánnych oblastiach. $\vee$ prvom rade budú popísané príčiny obnovenia konfliktu a detailne zmapovaný priebeh bojov vo vymedzenom období na tureckom území, pričom špecificky sa text bude zameriavat' na ozbrojené strety odohrávajúce sa medzi tureckými bezpečnostnými zložkami a PKK/KCK $\checkmark$ mestskom prostredí. Zámerom je podat' ucelený obraz na pomery PKK/KCK inovatívneho spôsobu boja a tiež popísat', ako sa tomuto vývoju dokázala prispôsobit' turecká strana. Z dátového hladiska sa text opiera tiež o informácie získané pomocou pološtruktúrovaných neformálnych rozhovorov uskutočnených s osobami z prostredia tureckej a kurdskej radikálnej lavice počas terénneho výskumu autora na juhovýchode Turecka na jar 2016 a v lete 2018. S ohladom na bezpečnost' autora a tiež osôb, s ktorými boli rozhovory uskutočňované, nie je uvedená ich identita a informácie takto získané slúžia predovšetkým ako potvrdenie či doplnenie informácií získaných z iných zdrojov.

\footnotetext{
${ }^{1}$ MANDIRACI, Berkay. Turkey`s PKK Conflict: The Death Toll. International Crisis Group [online]. 20.07.2016. [cit. 2020-03-03]. Dostupné na: https://bit.ly/2y2AaWU.
} 


\section{DAVID KILCULLEN A JEHO PREDSTAVA BOJISKA BUDÚCNOSTI}

David Kilcullen vo svojej knihe Out of the mountains: The coming age of the urban guerrilla na základe analýzy historických príkladov a súčasných trendov prichádza s tvrdením, že boj proti neštátnym aktérom bude aj nad'alej predstavovat' strategicky významný aspekt vedenia bojových operácií v budúcnosti. Zároveň však dodáva, že sa zásadne zmení prostredie, $v$ ktorom sa bude tento boj odohrávat', ked' sa presunie z horských oblastí do urbánnych zón. Argumentuje $v$ tomto prípade tzv. megatrendami, ako je rýchly populačný rast, urbanizácia, litoralizácia ${ }^{2}$ a zvyšujúca sa prepojenost'. Podla jeho názoru to tak budú husto obývané, pobrežné a prepojené mestá, ktoré budú reprezentovat' bojiská budúcnosti. ${ }^{3}$

Všeobecným zámerom textu je nadviazat' na Kilcullena a na príklade PKK/KCK ukázat', že prechod povstaleckých organizácii z horského prostredia do mestských zón nie len otázkou vzdialenej budúcnosti, ale aktuálnou realitou. Zároveň sa autor prostredníctvom prípadovej štúdie bude snažit' ukázat', že sa tento trend nemusí týkat' len pobrežných miest, ale aj vnútrozemských urbánnych zón, najmä v prípade, ked' povstalecká organizácia dlhodobo operuje $v$ regióne bez prístupu $\mathrm{k}$ pobrežiu a má $\mathrm{v}$ danej oblasti dlhodobú podporu. V neposlednom rade je zámerom textu pokúsit' sa prehĺbit pochopenie, ako môže vybraná povstalecká organizácia takúto zmenu bojiska uskutočnit' a na základe konkrétneho príkladu ponúknut' závery a odporúčania, ktoré by štát na strategickej úrovni a bezpečnostné a ozbrojené zložky na taktickej úrovni mali dodržiavat pri snahe o potlačenie či predídenie tohto typu ozbrojenej aktivity.

\section{PRÍČINY A UDALOSTI VEDÚCE K POVSTANIU}

\section{Občianska vojna v Sýrii}

Počiatky sledovanej fázy konfliktu medzi Tureckom a PKK/KCK je možné vystopovat' do záveru roku 2014, pričom úzko súvisia s vývojom občianskej vojny v susednej Sýrii, v ktorej sa PKK/KCK angažuje de facto od jej začiatku politicky, prostredníctvom svojej odnože, Zjednotenej demokratickej strany (PYD), a vojensky, nasadením '́udových obranných síl (YPG) atd'.

Ked' v septembri 2014 zahájili jednotky Islamského štátu (IS) svoju ofenzívu zameranú na ovládnutie Kobani ležiaceho na sýrsko-tureckej hranici, vyvolalo to paniku medzi civilným obyvatel'stvom a približne 200000 osôb (prevažne Kurdov) utieklo do Turecka. ${ }^{4}$ To vyvolalo značnú odozvu kurdskej populácie žijúcej v Turecku, ked' sa množstvo mladých Kurdov a lavicovo orientovaných Turkov rozhodlo spolu s členmi PKK/KCK prekročit' hranicu a podiel'at' sa na obrane mesta. V tom sa im snažili zabránit' turecké bezpečnostné zložky, ked' uzatvorili hraničný priechod v smere do Kobani. Obratom na to vypukli vo viacerých tureckých mestách masové pro-kurdské demonštrácie podporené výzvami PKK/KCK, pričom najväčšej z nich sa v Dyiarbakıre zúčastnilo okolo 15000 l'udí. $^{5}$

\footnotetext{
${ }^{2} \mathrm{Z}$ anglického littoralization, tj. rapídna urbanizácia pobrežných oblastí.

${ }^{3}$ KILCULLEN, David. Out of the mountains: The coming age of the urban guerilla. s. 27-40, Londýn: Hurst, 2015. ISBN 9781849045117.

${ }^{4}$ MIDDLE EAST EYE. Iraqi Kurdistan votes to send fighters to Kobane. [cit. 2020-03-03]. Dostupné na: https: //bit.ly/2LLNDG4.

${ }^{5}$ MIDDLE EAST EYE. Thousands protest in Turkey to show solidarity with Kobane Kurds. [cit. 202003-03]. Dostupné na: https://bit.ly/2zh34mX.
} 
Vo viacerých mestách juhovýchodného Turecka došlo k násilným stretom demonštrantov s policajnými zložkami, a tiež konfliktom medzi členmi kurdského Patriotického revolučného mládežníckeho hnutia (YDG-H), napojeného na PKK/KCK, a podporovatel'mi islamistickej Strany za slobodnú vec (Hüda-Par).

Vd'aka postoju Turecka začalo vedenie PKK/KCK a čast' kurdskej populácie obviňovat' Turecko zo zámernej neaktivity, či dokonca priamej podpory IS, ktorý mal plnit' úlohu tureckej proxy $v$ boji proti Kurdom $\vee$ Sýrii. ${ }^{6}$ Tento postoj ešte posilnilo viacero bombových útokov IS na kurdské ciele $v$ Turecku. Samotná PKK/KCK prejavila svoj nesúhlas s tureckým prístupom útokmi na policajné hliadky na dialnici medzi Diyarbakırom a Bitlisom koncom septembra 2014, pričom ich označila za varovanie tureckej vláde o tom, čo bude nasledovat', ak (Turecko) nezastaví svoje „vražedné konanie“. ${ }^{7}$

V októbri 2014 turecké letectvo prvýkrát od začiatku mierového procesu v roku 2012 bombardovalo pozície PKK/KCK na juhovýchode krajiny. Náletom predchádzalo ostrelovanie vojenských outpostov ozbrojencami PKK/KCK v blízkosti obce Dağlıca v provincii Hakkâri. Za rozbušku, ktorá skutočne spustila kolotoč násilia medzi Kurdami a tureckými ozbrojenými zložkami je ale možné označit' útok samovražedného atentátnika z 20. júla 2015 v meste Suruç, patriaceho k tureckej skupine Dokumacılar podporujúcej IS. Cielom boli lavicoví dobrovolníci plánujúci podielat' sa na rekonštrukcii bojmi zničeného Kobani. PKK/KCK zodpovednost' za útok pripisovala priamo Turecku a obvinila tureckú vládu z vedenia vojny voči kurdskému l'udu. ${ }^{8}$

Nasledujúce dni sa niesli $\vee$ znamení stupňujúcej sa ozbrojenej aktivity ozbrojencov patriacich pod PKK/KCK, zameranej voči tureckým bezpečnostným zložkám. 24. júla 2015, oficiálne kvôli paralelne sa stupňujúcej aktivite IS a PKK/KCK, začalo Turecko dvojdňovú leteckú operáciu Martyr Yalçın zameranú na IS v Sýrii a PKK/KCK v irackom Kurdistane. V reakcii na letecké útoky vydala PKK/KCK prehlásenie, v ktorom obviňuje tureckú vládu $\mathrm{z}$ jednostranného porušenia podmienok prímeria, vzhladom na čo nepovažuje jeho d'alšie dodržiavanie za zmysluplné. ${ }^{9}$ Práve 24., resp. 25. júl 2015 je tak možné označit' za začiatok d'alšej etapy ozbrojeného konfliktu medzi Tureckom a PKK/KCK.

\section{Vnútropolitický vývoj $v$ Turecku}

Pre pochopenie vývoja vedúceho k prepuknutiu konfliktu je tiež nevyhnutné spomenút' politicky motivované násilie spojené s parlamentnými volbami, ktoré sa v Turecku konali 7. júna 2015, resp. predčasnými parlamentnými volbami z novembra 2015. To ešte zvýšilo napätie medzi komunitami v krajine, a to najmä medzi nacionalistickou čast'ou tureckej verejnosti, islamistami z radov Kurdov a Turkov a kurdskou populáciou sympatizujúcou s PKK/KCK. Pri jednom incidente napr. príslušníci PKK/KCK zabili predstavitela mládežníckeho krídla nacionalistickej strany MHP, inokedy neznámi útočníci zaútočili strel'bou alebo podpálili viacero kancelárií pro-kurdskej L'udovo-demokratickej strany

\footnotetext{
${ }^{6}$ ZAMAN, Amberin. Exclusive: PKK commander threatens to resume war. AL-Monitor [online]. 25.09.2014. [cit. 2020-03-03]. Dostupné na: https: //bit.ly/3bPhY18.

${ }^{7}$ MIDDLE EAST EYE. Kurdish militants claim deadly ambush in Turkey's southeast. [cit. 2020-0303]. Dostupné na: https://bit.ly/2XeOleV.

${ }^{8}$ ANF NEWS. KCK: $\overline{A K P}$ directly responsible for the massacre of youths in Suruç. [cit. 2020-03-03]. Dostupné na: https: //bit.ly/2TlmUo0.

${ }^{9}$ ENSONHABER. PKK'dan küstah açıklama. [cit. 2020-03-03]. Dostupné na: https://bit.ly/2TnAd7B.
} 
(HDP). Napriek tomu, že samo o sebe sa nejedná o skutočnosti, ktoré by samostatne mohli zapríčinit' kolaps prímeria medzi PKK/KCK a Tureckom, vzniknutá situácia jednoznačne vytvorila vhodné podmienky $k$ obnoveniu boja zo strany PKK/KCK, ked' prispela k zaisteniu podpory lavicovo a nacionalisticky orientovanej časti prevažne kurdského obyvatel'stva a radikalizácii kurdskej mládeže, ktorá aj vd’aka tomu z vel'kej časti stratila vieru $v$ mierové riešenie konfliktu. ${ }^{10}$ Práve násilné aktivity mládeže, združenej $v$ YDG-H a zamerané voči tzv. sympatizantom IS, sa pravdepodobne v niektorých prípadoch vymkli $\mathrm{PKK} / \mathrm{KCK}$ spod kontroly a prispeli k všeobecne zvyšujúcemu sa napätiu. $V$ rozhovore $z$ roku 2014 Cemil Bayık tvrdil: „Naša mládež je plná hnevu. Dokonca aj my máme problém zvládnut' ju. “11

Kurdsko-tureckú dôveru neprehíbili ani kontroverzie naznačujúce viaceré volebné podvody, či nekalé praktiky v prospech vládnej Strany spravodlivosti a rozvoja (AKP), ktorá aj napriek tomu nedokázala po prvých vol'bách v júni 2015 zostavit' vládu. Ešte pred nimi sa objavili obvinenia hovoriace o tom, že ciel'om prezidenta Erdoğana je len využit' mierový proces s PKK/KCK pre zisk ústavnej väčšiny vo vol'bách, ktorá by mu umožňovala prepísat' ústavu a nastolit' v krajine prezidentský systém. HDP však malo tento plán narušit' rozhodnutím kandidovat' do volieb ako strana, namiesto očakávaného nasadenia nezávislých. ${ }^{12}$ Príčinou stojacou za nedodržiavaním dohody s PKK/KCK tak mali byt' predovšetkým predvolebné prieskumy ukazujúce, že snahy o pokračovanie mierového riešenia konfliktu s PKK/KCK neprinášajú želaný efekt v podobe nárastu hlasov pre AKP. ${ }^{13}$

Pred následnými predčasnými volbami potom kritici z radov kurdskej menšiny, či predstavitelia HDP obviňovali Erdoğana zo zámerného vyvolania konfliktu s PKK/KCK, ktorý mal zvýšit' volebnú podporu AKP, zabezpečit' AKP povolebnú podporu zo strany nacinalistickej strany MHP, a zároveň znížit' volebnú účast' v juhovýchodnom Turecku, tradičnej bašte HDP. V praxi prezident Erdoğan, po neúspechu v júnových parlamentných vol'bách, ked' jeho strana AKP nebola schopná samostatne zostavit' vládu, absolútne rezignoval na pokračovanie mierového procesu s PKK/KCK. Po opakovaných vol'bách v novembri 2015 ustanovil vládu práve s podporou MHP, ktorá bola dlhodobo proti mierovému procesu s PKK/KCK. ${ }^{14}$

Samotný výsledok júnových volieb ale paradoxne mohol vyvolat' nespokojnost' nielen na strane AKP, ale aj PKK/KCK. Kým vo všeobecnosti bolo HDP označované za klúčový nástroj Öcalanovej mierovej stratégie, podla niektorých názorov sa vedenie PKK/KCK v Kandíle zlaklo dobrého výsledku HDP vo vol'bách, ktorý by mohol znamenat' ohrozenie dlhoročného

\footnotetext{
10 JOHNSON, Glen. New generation of more radical youth emerges in the Kurdish region of Turkey. Los Angeles Times [online]. 21.03.2016. [cit. 2020-03-03]. Dostupné z:

https: / /lat.ms/3bmNSIA.

11 ZAMAN, Amberin. Syrian Kurds continue to blame Turkey for backing ISIS militants. Al-Monitor [online]. 25.09.2014. [cit. 2020-03-03]. Dostupné z: https://bit.ly/2UeHYOl.

12 GÖKSEL, Nigar \& MANDIRACl, Berkay. New turkey-pkk peace talks: an inevitability postponed. Turkish Policy Quarterly [online]. 07.03. 2016, vol. 14, č. 4. [cit. 2020-03-03]. Dostupné na: https: / /bit.ly/2Tu2FES.

13 TAȘTEKIN, Fehim. Will Erdogan's backtracking torpedo PKK disarmament? Al-Monitor

[online].06.05. 2015. [cit. 2020-03-03]. Dostupné z: https://bit.ly/2zSsW8M.

14 PLAKOUDAS, Spyridon. Insurgency and Counter-Insurgency in Turkey:

The New PKK. Cham: Palgrave Pivot, 2018. ISBN 978-3-319-75658-5.
} 
dominantného postavenia PKK/KCK v rámci kurdskej populácie $v$ Turecku. ${ }^{15}$ Ukončenie mierového procesu ako prostriedok $\mathrm{k}$ riešeniu $\mathrm{z}$ ich pohladu nepriaznivej situácie tak mohli vnímat' obe strany ako prospešné.

\section{Nedôvera medzi PKK/KCK a Tureckom}

Za neúspechom mierového procesu PKK/KCK a Tureckom je možné hladat' tiež nedôveru panujúcu medzi oboma stranami aj po uzatvorení prímeria z marca 2013. Napriek nemu aj nad’alej dochádzalo k občasným ozbrojeným stretom medzi PKK/KCK a tureckými ozbrojenými zložkami a panovali tiež pochybnosti o zámeroch na oboch stranách. V skratke, kým turecká strana obviňovala PKK/KCK primárne z neochoty zložit' zbrane a dodržat' dohodu o stiahnutí bojovníkov do severného Iraku, PKK/KCK sa obhajovala nedodržiavaním podmienok mierového procesu zo strany tureckej vlády a zdôrazňovala, že Turecko len využíva prímerie na posilnenie vojenskej prítomnosti na juhovýchode krajiny prostredníctvom tzv. militarizovaných rozvojových projektov (priehrady, pozemné komunikácie atd'.). ${ }^{16}$

17. júla 2015 navyše prezident Erdoğan otvorene odmietol platnost' tzv. Dohody z Dolmabahçe, 10 bodového plánu vyjednaného medzi tureckou vládou, Öcalanom a vedením PKK/KCK v Kandíle za sprostredkovania HDP vo februári 2015, predstavujúceho dlhodobú stratégiu k dosiahnutiu mieru s PKK/KCK. Dôvodom malo byt' prepojenie HDP a PKK/KCK. Turecko zároveň obnovilo izoláciu Öcalana vo väzení, pričom Erdoğan obviňoval PKK/KCK z neochoty zložit' zbrane a deklaroval, že v Turecku neexistuje kurdský problém. PKK/KCK preto odmietla zložit' zbrane, ako požadovala dohoda. ${ }^{17}$

\section{PRIEBEH POVSTANIA}

Zámerom textu je zachytit' ucelený priebeh celej jednej fázy povstania charakteristickej intenzívnou bojovou činnost'ou v urbánnych zónach. Časový rámec je tak ohraničený júlom 2015, ked' došlo k definitívnemu kolapsu mierového procesu medzi Tureckom a PKK/KCK a októbrom 2016, ked' bol odpor PKK/KCK v urbánnych zónach zlomený a povstalecká organizácia kvôli nástupu zimy z vel'kej časti pozastavila aj aktivity rurálnej guerrilly. Vo vymedzenom období je možné identifikovat' tri základné fázy povstania na základe dominantného prostredia ozbrojenej činnosti, tj. rurálnych alebo urbánnych oblastí: júl-október 2015, november 2015-apríl 2016 a máj-október 2016. Uvedené mesiace sú $v$ tomto prípade skôr orientačným ukazovatel'om ulahčujúcim zachytenie istých trendov, než exaktným časovým údajom vzhl'adom na to, že povstanie je komplexný dynamický fenomén.

\footnotetext{
15 ERCAN, Harun. Is Hope More Precious than Victory?: The Failed Peace Process and Urban Warfare in the Kurdish Region of Turkey. South Atlantic Quarterly [online]. 01. 01. 2019, vol. 118, č. 1. [cit. 2020-03-03]. Dostupné na: https://bit.ly/3g9nJdq.

${ }^{16}$ LINDENSTRAUSS, Gallia. Back to Square One? The Collapse of the Peace process with the Kurds. Strategic assessment [online]. Jan. 2016, vol. 18, č. 4. [cit. 2020-03-03]. Dostupné na: https://bit.ly/3e97viJ.

17 lbid.
} 
Stupňujúce sa napätie v mestách na pozadí rurálnych bojov (Júl 2015-Október 2015)

\section{Povstalecká aktivita PKK/KCK}

V období od júla do októbra 2015 je možné hovorit' o prevažujúcej aktivite PKK/KCK v rurálnych oblastiach na juhovýchode, čo dosvedčuje aj infografika z dielne International Crisis Group, ktorá v sledovanom období vykazuje 69 \% celkových strát na životoch zapríčinených konfliktom práve na vidieku. ${ }^{18}$

Hoci v tomto období bola urbánna ozbrojená aktivita PKK/KCK v pozadí útokov v rurálnych oblastiach, neznamená to, že zohrávala nevýznamnú úlohu. Už v auguste sa tureckí predstavitelia vyjadrili, že potlačenie nepokojov v mestách na juhovýchode (Cizre, Şırnak, Silopi, Diyarbakır atd'.) si vyžaduje viac ako len bežné prostriedky. ${ }^{19}$ Práve $\checkmark$ reakcii na situáciu $v$ Cizre vydala PKK/KCK vyhlásenie, $v$ ktorom $v$ septembri vyzýva na totálny odpor voči „teroru tureckých ozbrojených zložiek“. ${ }^{20}$ Prevažne členovia YDG-H, vyzbrojení improvizovanými výbušnými zariadeniami (IED), molotovmi, ručnými strelnými zbraňami, výnimočne granátmi a ručnými protitankovými granátometmi, sa snažili aj za pomoci barikád a zákopov zabránit' tureckým bezpečnostným zložkám $v$ obnovení kontroly nad vybranými štvrt’ami, ktoré vyhlásili na popud PKK/KCK za tzv. autonómne zóny s vlastnou správou. ${ }^{21}$ Prvá z nich sa objavila v priebehu augusta 2015 v reakcii na operácie tureckého režimu zamerané voči PKK/KCK. ${ }^{22}$ Symbolom úvodných stretov $v$ mestách sa stalo najmä mesto Cizre. Zo strany YDG-H sa nejednalo o vysoko organizovaný odpor v zmysle využitia vojenskej taktiky. Charakteristické je použitie IED a najmä útokov „udri a uteč“ voči tureckým bezpečnostným zložkám, často s mizivým účinkom a v nočných hodinách. Objavujú sa tiež prípady, ked’ sú príslušníci spomenutých zložiek terčom útokov vykazujúcich znaky popravy - zvyčajne sa jednalo o útoky voči osobám, ktoré mali páchat' zločiny voči Kurdom v minulosti, či o odvetu za zabitie blízkej osoby.

Začiatkom jesene je už možné predpokladat' tiež zapojenie menšieho počtu vycvičených kádrov Ĺudových obranných síl (HPG), predstavujúcich hlavnú bojovú zložku PKK/KCK, po boku YDG-H v niektorých mestách, čo naznačilo aj vyjadrenie velenia HPG z augusta. ${ }^{23}$ Tomu by mohol zodpovedat' aj fakt, že napríklad v Silvane nasadila turecká strana v auguste a novembri aj t’ažkú techniku, vrátane tankov.

18 ICG. Turkey’s PKK Conflict: A Visual Explainer. [cit. 2020-03-03]. Dostupné na: https: / /bit.ly/2UaMWv5.

${ }^{19}$ ALBAYRAK, Ayla. Urban Warfare Escalates in Turkey's Kurdish-Majority Southeast. In: Wall Street Journal Times [online]. 18.08. 2015. [cit. 2020-03-03]. Dostupné na:

https: //on.wsj.com/2UeKOm1.

${ }^{20}$ ANF NEWS. KCK calls upon all Kurdistan people to rise up everywhere. [cit. 2020-03-03]. Dostupné na: https://bit.ly/398all2.

21 ONAT, Ismail \& ÇUBUKÇU, Suat. Unresolved conflict, urban insurgency and devastating consequences in Turkey between 2015 and 2016. Journal of Policing, Intelligence and Counter Terrorism [online]. 07.05. 2019, vol. 14, č. 2. [cit. 2020-03-03]. Dostupné na:

https://bit.ly/3e9k5P1.

22 PFHR. Southeastern Turkey: Health Care under Siege. [cit. 2020-03-03]. Dostupné na: https: / /go.aws/2WAEvuv.

${ }^{23}$ MACDONALD, Alex. PKK threatens to send fighters to southeast Turkey as violence flares. Middle East Eye [online]. 18.08.2015. [cit. 2020-03-03]. Dostupné na: https://bit.ly/3bnZkhc. 
Kým drvivá väčšina ozbrojenej činnosti sa udiala na juhovýchode, v menšej miere dochádzalo tiež k násilným demonštráciám a aktivitám YDG-H na západe Turecka. To, spolu s ojedinelými útokmi PKK/KCK na policajné ciele $v$ Istanbule, sa dá označit' za znamenie toho, že PKK/KCK podporená lokálnou kurdskou mládežou sa už v úvode konfliktu snažila o prenesenie násilia aj do mestských centier na západe krajiny.

\section{Protipovstalecká aktivita tureckej strany}

V úvode vymedzenej fázy sa turecká strana zamerala predovšetkým na letecké a delostrelecké bombardovanie pozícií PKK/KCK v rurálnych oblastiach irackého Kurdistanu a v juhovýchodnom Turecku. Počas celého konfliktu boli uskutočňované protiteroristické operácie zamerané na zatknutie členov či podporovatelov PKK/KCK, počas ktorých bolo len od útoku $\vee$ Suruçi do 18. augusta zadržaných 1375 členov strany HDP. ${ }^{24}$

Na stupňujúcu sa ozbrojenú aktivitu HPG a Jednotiek slobodných žien (YJA-STAR) ${ }^{25}$ $\checkmark$ rurálnych oblastiach následne turecké bezpečnostné zložky reagovali outpostami a checkpointami doplnenými o mobilné zložky schopné prenasledovat' útočníkov po odrazení útoku a vyhlasovaním tzv. bezpečnostných a vojenských zón, v rámci ktorých prebiehali kombinované pozemno-letecké operácie. ${ }^{26}$ Primárnou reakciou na ozbrojenú aktivitu YDG-H v mestách sa stalo predovšetkým vyhlasovanie zákazov vychádzania, ktoré boli len do júla 2016 nariadené minimálne 85-krát v 33 prevažne Kurdmi obývaných okresoch juhovýchodného Turecka. ${ }^{27}$ Zámerom bolo pravdepodobne nielen deklarované obmedzenie civilných strát, ale tiež zamedzenie vstupu mimovládnym organizáciám do daných oblastí a limitovanie manévrovacej schopnosti YDG-H.

Proti YDG-H Turecko v priebehu niekol'kých nasledujúcich mesiacov nasadzovalo prevažne posilnené policajné sily a špeciálne jednotky vrátane obrnených vozidiel. Okrem slzného plynu boli proti YDG-H využívaní tiež ostrelovači. Vo vybraných prípadoch sa objavilo aj nasadenie armády s t’ažkou technikou, ako tomu bolo v Silvane. Objavili sa tiež správy hovoriace o porušovaní ludských práv a vysokých stratách na strane civilistov, napr. pri obliehaní Cizre a práve Silvanu. ${ }^{28}$ Tie mali mat' na svedomí najmä tzv. Esedullah Timi, akési paramilitárne jednotky zložené z konzervatívnych moslimov. ${ }^{29}$ Turecká strana nereagovala na prímerie vyhlásené PKK/KCK po bombových útokoch IS na pro-kurdskú mierovú demonštráciu $v$ Ankare začiatkom októbra a pokračovala pozemných a aj

\footnotetext{
24 STEIN, Aaron. Turkey's Counterterrorism Policies: Targeting ISIS and the PKK. Atlantic Council [online]. 27.08.2015. [cit. 2020-03-03]. Dostupné na: https://bit.ly/2UaUSfR.

25 Jedná sa o ženskú verziu HPG, tj. rurálne guerrillové jednotky.

${ }^{26}$ GÜRCAN, Metin. Ankara hardening anti-PKK strategy. Al-Monitor [online]. 12.09.2016. [cit. 2020-03-03]. Dostupné na: https://bit.ly/2QEJ03z.

27 TIHV. Curfews in Turkey Between 16 August 2015 - 12 December 2015. [cit. 2020-03-03]. Dostupné na: https: //bit.ly/2UdDmaX.

${ }^{28}$ HUMAN RIGHTS WATCH. Turkey: Mounting Security Operation Deaths: Scores of Civilians Among Hundreds Killed in Southeast. [cit. 2020-03-03]. Dostupné na: https://bit.ly/39cYjH9.

${ }^{29}$ CENGIZ, Orhan Kemal. Who are 'Allah's lions'?. Al-Monitor [online]. 25.11.2015. [cit. 2020-0303]. Dostupné na: https://bit.ly/2UveSbz.
} 
leteckých operáciách. Jednostranné prímerie Turci interpretovali ako náznak bližiacej sa porážky povstaleckej organizácie. ${ }^{30}$

\section{Boje v mestách a aktivizácia Sokolov oslobodenia Kurdistanu (TAK) (November 2015- Apríl 2016)}

\section{Povstalecká aktivita PKK/KCK}

Predčasné parlamentné vol'by z 1 . novembra skončili získaním parlamentnej väčšiny pre stranu AKP, pričom pro-kurdská HDP obhájila štvrté miesto so ziskom vyše $10 \%$ z celkového počtu hlasov. Posilnený volebným úspechom, prezident Erdoğan sa svojim voličom zaviazal zlikvidovat' PKK/KCK. Deň na to, 5. novembra, ohlásila PKK/KCK koniec jednostranného prímeria a vyzvala „kurdskú populáciu $v$ Turecku, turecký l'ud a demokratické sily na vystupňovanie boja“. ${ }^{31}$

Z geografického hladiska bola PKK/KCK aktívna opät' najmä na juhovýchode Turecka, a to predovšetkým v provincii Şırnak a jej mestských sídlach Cizre, Şırnak, Silopi, nasledovaných provinciami Diyarbakır (Diyarbakır), Mardin (Nusaybin) a Hakkâri (Yüksekova). ${ }^{32}$ Do ozbrojenej aktivity PKK/KCK sa preniesol nástup zimného počasia, ktorý viedol $\mathrm{k}$ postupnému znižovaniu intenzity útokov $\mathrm{v}$ rurálnych oblastiach.

Za skutočný začiatok urbánnych bojov je možné označit' december 2015, ked' Turecko uvalilo zákazy vychádzania v Sure, Cizre, Silopi a Nusaybine a turecké bezpečnostné zložky následne zaútočili na autonómne zóny vyhlásené $v$ týchto mestách YDG-H. ${ }^{33}$ To, že vyhlasovanie týchto zón a začiatok odporu nemusel byt' vždy priamo pod kontrolou PKK/KCK naznačujú aj vyjadrenia z prostredia organizácie, ktoré autor získal, ked poukazovali, že napr. v Nusaybine sa jednalo o spontánne rozhodnutie miestnej odnože YDG-H. Najmä mesiace marec a apríl je možné označit' za klúčové, ked'že práve vtedy sa odohrali najzúrivejšie strety medzi PKK/KCK a tureckými bezpečnostnými zložkami v Cizre, Nusaybine, Silopi, Șırnaku a mestskej časti Sur v Diyarbakıre. Hoci urbánne boje doznievali až do začiatku júna 2016, od mája 2016 je už možné hovorit' len o doznievajúcom odpore, pričom prím začali hrat' znova operácie na vidieku.

Početne najviac zastúpenou zložkou $v$ týchto bojoch na strane PKK/KCK boli lokálni členovia YDG-H, ktoré sa $v$ decembri transformovalo na Občianske obranné jednotky (YPS). Ako potvrdzujú aj autorove rozhovory z Diyarbakıru, vo väčšine prípadov im bol na pomoc vyslaný menši počet ozbrojencov HPG, ktorý sa prejavil aj $v$ postupne narastajúcich stratách príslušníkov HPG od februára 2016, a to aj napriek relatívne nízkej aktivite $v$ rurálnom prostredí. ${ }^{34}$

Napríklad v Sure sa k približne stovke bývalých členov YDG-H, prevažne študentov miestnej univerzity, malo podla autorových informácií pridat' asi 70 príslušníkov HPG, ktorí spolu vytvorili lokálnu zložku YPS a odolávali tureckým útokom vyše dvoch mesiacov,

\footnotetext{
30 HÜRRIYET. Terör saldırılarında 93 günlük bilanço: Bin 740 terörist öldürüldü. [cit. 2020-03-03]. Dostupné na: https://bit.ly/2xfalPE.

${ }^{31}$ BUTLER, Daren. Kurdish PKK militants end unilateral ceasefire in Turkey: agency. Reuters [online]. 05.11.2015. [cit. 2020-03-03]. Dostupné na: https://reut.rs/2vFwBF8.

32 ICG, ref. 18

33 lbid.

34 lbid.
} 
pričom mali spôsobit' tureckým ozbrojeným zložkám straty vo výške takmer 70 mužov, niekol'kých obrnených vozidiel a údajne aj tankov. V prípade Nusaybinu, kde malo byt' nasadených okolo 250 ozbrojencov, trvalo obliehanie ešte dlhšie.

Po zapojení členov HPG do bojov v mestách bolo možné vidiet' rozsiahlu aplikáciu inovácii v taktike, ktoré si PKK/KCK priviezla zo Sýrie. Úzke uličky starého mesta boli prekryté plachtami kryjúcimi bojovníkov pred leteckou aktivitou tureckých zložiek a pred tureckými ostrel'ovačmi, steny domov boli prebúrané, a umožňovali tak skrytý presun jednotiek. Počas bojov v mestách padlo množstvo tureckých policajtov a vojakov za obet' výbušným zariadeniam nastraženým $v$ budovách, či barikádach blokujúcich vstup tureckých jednotiek do jednotlivých štvrtí. Objavili sa tiež rafinovane zamaskované IED, napr. vo forme Koránu.

Vedla častejšieho využitia IED boli zvýšené straty na tureckej strane tiež výsledkom nasadenia ostrelovačov, napr. $\vee$ Sure, Cizre a Nusaybine. Okrem tradičných zbraní $v$ podobe pištolí, automatických pušiek, ručných protitankových granátov, tzv. molotov sa začali objavovat' tiež špecifickejšie zbrane ako tzv. čajníkové bomby naplnené zmesou dusičnanu amónneho získavaného $z$ hnojiva a nafty či antimateriálové pušky Zagros. ${ }^{35}$ Nasadenie pušiek Zagros $v$ mestskej zástavbe bolo podmienené predovšetkým terénnym profilom, ked' sa objavili napr. v Nusaybine disponujúcom širokými dlhými ulicami, kým úzke, krivolaké uličky starého mesta v Sure ich nasadenie nedovolili.

Okrem presunu t’ažiska z rurálnych operácií na urbánne nastala v popisovanej fáze ešte jedna zásadná zmena. Tou je aktivizácia teroristickej organizácie TAK, s najväčšou pravdepodobnost'ou vol'ne podriadenej vedeniu PKK/KCK a operujúcej v mestských centrách na západe Turecka. V prípade prvého útoku TAK, ktorým bolo mínometné ostrel'ovanie letiska $v$ Istanbule, je vhodné venovat' pozornost' tomu, kedy sa odohral. Bolo to len pár dní po tom, čo bolo ohlásené založenie YPS a zároveň len pár dní predtým, ako kurdský Kongres demokratickej spoločnosti (DTK) v Diyarbakıre vyjadril potrebu autonómie pre Kurdov v Turecku a Demirtaş, predseda HDP, volal po všeobecnom odpore voči postupu Turecka $v$ mestách na juhovýchode. ${ }^{36,37}$ Rýchlost', s akou TAK dokázali zareagovat' na spomenutý vývoj $v$ krajine, naznačuje minimálne základnú úroveň koordinácie s PKK/KCK.

Tento a d'alšie útoky mali byt' odpoved'ou na vojenské operácie voči PKK/KCK v Cizre, Sure a d'alších mestách. ${ }^{38}$ Do mája 2015 uskutočnili TAK ešte d’alšie štyri útoky: útoky samovražedných atentátnikov vo vozidle naloženom výbušninami (SVBIED) na vojenský autobus $\vee$ Ankare, autobusy mestskej hromadnej dopravy $\vee$ Ankare, útok ručným protitankovým granátom na postavenie žandarmy blízko Izmiru, strelbu na vozidlo žandarmy $\vee$ tej istej oblasti a odpálenie samovražednej atentátničky $\vee$ mešite $v$ Burse. Dokopy si spomenuté štyri útoky vyžiadali vyše 60 obetí, z velkej časti civilistov,

\footnotetext{
${ }^{35}$ HÜRRIYET DAILY NEWS. PKK militants make 'teapot bombs,' hide explosives in walls. [cit. 202003-03]. Dostupné na: https://bit.ly/2UeCdzy.

36 HÜRRIYET DAILY NEWS. HDP asks for autonomy, as PM cancels meeting on constitution dialogue struggle. [cit. 2020-03-03]. Dostupné na: https://bit.ly/2vHZD76.

37 KURDISH QUESTION. HDP Co-Chair Demirtaș Urges Allout Resistance Against Turkish State

Terror And Curfews. [cit. 2020-03-03]. Dostupné na: https: / /bit.ly/2zOgNBL.

${ }^{38}$ AL JAZEERA. Ankara bombing: Kurdish group claims responsibility. [cit. 2020-03-03]. Dostupné na: https: //bit.ly/2WE3o8E.
} 
a približne 200 zranených. ${ }^{39}$ Kým aktivita PKK/KCK v tureckých metropolách na západe krajiny bola v priebehu minulej fázy len symbolická, aktivita TAK od decembra 2015 ukázala, že mestá ako Istanbul, či Ankara sa stali naplno súčast’ou ozbrojeného konfliktu, ktorý dovtedy prebiehal primárne na juhovýchode Turecka.

\section{Protipovstalecká aktivita tureckej strany}

Príchod zimných mesiacov sa prejavil aj na aktivite tureckých bezpečnostných zložiek. Pozemné protipovstalecké operácie $v$ rurálnych oblastiach postupne ustával $s$ tým, ako sa stával terén t’ažšie priechodným. Letecká ofenzíva však pokračovala, nálety F-16 a F-4 boli navádzané zvyčajne prieskumnými dronmi. ${ }^{40}$

Odlišná situácia panovala $v$ mestách, kde Turecko zvolilo aktívny postup voči aktivitám PKK/KCK. Na mestá, či mestské časti, v ktorých sa koncentrovali ozbrojenci YDG-H a neskôr YPS posilnené o členov HPG, boli uvalené zákazy vychádzania trvajúce často niekol'ko mesiacov, počas ktorých policajné a armádne zložky (špeciálne policajné jednotky PÖH, špeciálne jednotky žandarmy JÖH, špeciálne armádne sily a obrnené jednotky) za použitia obrnených vozidiel, tankov, prieskumných dronov a bojových helikoptér tieto tzv. autonómne oblasti vyčist'ovali. ${ }^{41}$

Zvyčajný postup zahŕňal obklúčenie takejto časti mesta a jej odrezanie od zvyšku sveta, aby sa zabránilo posilneniu jednotiek PKK/KCK vo vnútri, či naopak ich úniku z obklúčenia. Následne bola spustená pozemná operácia sprevádzaná delostreleckým ostrelovaním či bodovými útokmi bojových helikoptér na silno bránené budovy. V postupe pomáhali tiež tanky, ktoré vytvárali priechody v budovách pre pechotu, ktorá často nemohla postupovat' ulicami z dôvodu zamínovaných barikád ostrelovaných pal'bou vedenou z jednotlivých domov. Prípadné demonštrácie, ako tá v Diyarbakıre proti zákazu vychádzania a izolácií obklúčenej štvrte Sur s civilným obyvatel'stvom vo vnútri, boli rozohnané vodnými delami a slzným plynom. ${ }^{42}$

Mimo obliehaných zón prebiehali nepravidelne protiteroristické akcie zamerané voči členom i podporovatelom PKK/KCK, ale tiež skladiskám zbraní a munície. Ich dôležitost' sa ukázala napr. v Diyarbakıre, kde bol približne dva týždne pred celkovou porážkou odporu odhalený vel'ký sklad zbraní a munície len pár ulíc od obklúčenej oblasti, ktorými PKK/KCK plánovala posilnit' svoje obliehané jednotky. Okrem iného sa pri nich podarilo zaistit' niekol'ko prieskumných dronov RQ-20 Puma, ktoré sa na turecké územie dostali pravdepodobne $z$ amerických dodávok pre YPG. ${ }^{43}$

Vo viacerých prípadoch boli zatknutí lokálni predstavitelia HDP či prokurdskej Demokratickej strany regiónov (DBP), ktorí mali byt' zapojení do dodávok zbraní pre

${ }^{39}$ GTD. Kurdistan Freedom Hawks. [cit. 2020-03-03]. Dostupné na: https://bit.ly/2WEaYAm.

40 DAILY SABAH. Turkish drone 'Bayraktar' guides Turkish security forces to kill six PKK terrorists. [cit. 2020-03-03]. Dostupné na: https://bit.ly/2J6h5p5.

41 GÜRCAN, Metin. Ankara Vs. The Pkk: Old War, New Strategies. Turkish Policy Quarterly [online]. 07.03.2016. [cit. 2020-03-03]. Dostupné na: https://bit.ly/2vN8K6G.

42 CAKAN, Seyhmus. Clashes in southeast Turkey kill seven, new curfews declared. Reuters.

[online]. 14.12. 2015. [cit. 2020-03-03]. Dostupné na: https://reut.rs/2wulz4Q.

43 HÜRRIYET DAILY NEWS. Drone used by PKK found in southeast Turkey. [cit. 2020-03-03].

Dostupné na: https://bit.ly/33Db50v. 
PKK/KCK a mali organizácii tiež umožňovat' využívanie majetku niektorých samospráv na juhovýchode krajiny.

\section{V tieni pokusu o prevrat: Návrat k rurálnym bojom (Máj 2016- Október 2016)}

\section{Povstalecká aktivita PKK/KCK}

Po finálnom vyčistení posledných ohnísk odporu v Nusaybine koncom mája sa dejiskom ozbrojeného konfliktu stali opät' prevažne rurálne oblasti juhovýchodu Turecka, konkrétne dve provincie na turecko-irackom pohraničí: Hakkâri a Şırnak. ${ }^{44}$ Kým intenzita bojových operácií PKK/KCK po porážke v mestách najprv signifikantne poklesla, po júlovom pokuse o prevrat v krajine začala znova stúpat', čo môže byt' náznakom toho, že sa organizácia snažila využit' oslabenie tureckých bezpečnostných zložiek v dôsledku poprevratových čistiek. Ako udáva Mandıracı:

„....kým celkové číslo príslušníkov štátnych bezpečnostných zložiek zabitých počas šiestich týždňov pred pokusom o prevrat bolo 51 (1,1 denne), v nasledujúcich šiestich týždňoch sa toto číslo takmer zdvojnásobilo na 96 (2,1 denne). "

Na vystupňovanie bojových operácií malo tiež vplyv spustenie operácie Euphrates Shield koncom augusta, v rámci ktorého vstúpili turecké jednotky na sýrske územie. Tomu nasvedčovalo aj vyjadrenie PKK/KCK, v ktorom obviňovala Turecko, že jeho hlavným cielom nie je IS, ale Kurdi. ${ }^{46}$

Popri juhovýchode Turecka bol dejiskom konfliktu opät' aj západ a turistická oblast' na juhu krajiny. Dvakrát v Istanbule a raz na ceste medzi Antalyou a Kemerom zaútočili TAK, ktorí sa prihlásili tiež $\mathrm{k}$ útoku $\vee$ Diyarbakıre zo začiatku novembra. ${ }^{47}$ Bolo to prvýkrát, čo TAK vykonali útok $v$ oblasti tureckého Kurdistanu. Práve po prvom útoku v Istanbule vyzval predseda HDP Demirtaș TAK k ukončeniu bojových operácií a rozpusteniu skupiny. ${ }^{48}$ Väčšinu operácií uskutočnili opät' jednotky HPG, ktoré pravdepodobne posilnila čast' bývalých kádrov YPS. Samotná YPS v podstate prestala vyvíjat' aktívnu ozbrojenú činnost'. Výnimku predstavovali len ojedinelé strety pri policajných raziách voči konšpiračným bytom. Primárnym cielom útokov HPG ostávali turecké bezpečnostné zložky v regióne, pričom sa častejšie objavovali tiež útoky na dedinské stráže, čo súvisí pravdepodobne s nárastom ich významu v celkovej tureckej stratégii. ${ }^{49}$ Typické útoky zahŕňali prepady základní a outpostov tureckej armády a žandarmy $v$ rurálnych oblastiach, vo výnimočných prípadoch až desiatkami ozbrojencov HPG a YJA-STAR, za použitia ručných palných

\footnotetext{
${ }^{44}$ ICG, ref. 18

${ }^{45}$ MANDIRACI, Berkay. Turkey's PKK Conflict Veers onto a More Violent Path. International Crisis Group. [online]. 10.11. 2016. [cit. 2020-03-03]. Dostupné na: https://bit.ly/3ahiEfU.

${ }^{46}$ ANF NEWS. KCK: Attack on Rojava is an attack on all Kurds. [cit. 2020-03-03]. Dostupné na: https: / / bit.ly/2WBUMiR.

47 GTD, ref. 39

48 HÜRRIYET DAILY NEWS. HDP co-chair condemns terror attacks on civilians. [cit. 2020-03-03].

Dostupné na: https://bit.ly/2QGYKmz.

${ }^{49}$ ICG, ref. 18
} 
zbraní, mínometov, či ručných protitankových granátov. ${ }^{50,51}$ Častým javom boli tiež útoky na vojenské či policajné vozidlá, najmä pomocou IED umiestnených v blízkosti cestných komunikácií. Objavilo sa tiež viacero prípadov využitia IED umiestnenom vo vozidle (VBIED), či už odpálených na dial'ku. alebo použitím samovražedného atentátnika pri útokoch na policajné či armádne budovy $\mathrm{v}$ rurálnych aj urbánnych oblastiach. ${ }^{52}$ V auguste 2016 si IED a VBIED vyžiadali zatial' najvyššie straty na životoch príslušníkov tureckých bezpečnostných zložiek v priebehu konfliktu, t.j. 47 obetí. ${ }^{53}$

Zároveň sa objavili dve novinky. Prvú z nich predstavovalo použitie prenosného protilietadlového raketového kompletu krátkeho dosahu (MANPAD) 9K38 Igla jednotkami HPG v máji, ked' zostrelili tureckú helikoptéru AH-1W Super Cobra počas protipovstaleckej operácie v provincii Hakkâri. ${ }^{54}$ Takéto limitované využitie MANPAD však naznačuje, že sa jednalo len o nepočetne zastúpenú zbraň v rukách PKK/KCK, ako ostatne autorovi potvrdili osoby blízke organizácii, ked' v júni 2016 hovorili asi o 15 kusoch MANPAD v rukách povstalcov. Práve dostatočný počet tohto typu zbraní by mohol znamenat' zásadnú zmenu $v$ priebehu konfliktu, ked’ by zbavil turecké zložky klúčovej vzdušnej podpory. Druhou novinkou je rozsah útokov na tureckých politických predstavitelov od augusta, zahŕňajúcich strel'bu na vozidlo predsedu Republikánskej ludovej strany (CHP) a popravu viacerých lokálnych predstavitelov AKP a správcov dosadených AKP namiesto odvolaných starostov miest v tureckom Kurdistane..$^{55}$ Oproti predchádzajúcej fáze nastala zmena $v$ útokoch TAK, ked' sa primárnymi ciel'mi stali výhradne bezpečnostné zložky, konkrétne SVBIED útok na policajný autobus $v$ Istanbule, útok IED umiestnenou na motocykli (MBIED) na policajnú stanicu v Istanbule a ostrelovanie vozidla žandarmy na ceste medzi Antalyou a Kemerom. ${ }^{56}$

\section{Protipovstalecká aktivita tureckej strany}

Po potlačení posledného signifikantného odporu $v$ Nusaybine deklarovali turecké ozbrojené zložky začiatkom júna presun operácií do rurálnych oblastí. To ale neznamená, že urbánne centrá opustili. Ako mal možnost' autor na vlastné oči vidiet' v Diyarbakıre a Cizre, aj niekolko mesiacov po skončení bojov hliadkovalo $v$ mestách velké množstvo policajtov vyzbrojených automatickými zbraňami, pričom jednotlivé improvizované outposty a policajné zátarasy boli doplnené o obrnené vozidlá. Zákazy vychádzania trvajúce v mnohých prípadoch aj niekol'ko mesiacov boli stále bežnou praxou, i ked' sa ich využitie stalo bežné skôr $v$ rurálnych oblastiach. Turecko tak zjavne nechcelo dopustit' prípadný návrat ozbrojených zložiek PKK/KCK do miest a dedín. Nový turecký premiér

\footnotetext{
${ }^{50}$ ANF NEWS. At least 39 soldiers killed in ongoing guerrilla actions. [cit. 2020-03-03]. Dostupné na: https: / /bit.ly/2WB4Rg4.

51 EKURD DAILY. PKK says destroys three Turkish military helicopters in the Kurdish region. [cit. 2020-03-03]. Dostupné na: https: //bit.ly/2wzGXH0.

${ }^{52} \mathrm{MANDIRACl}$, ref. 45

53 ICG, ref. 18

${ }^{54}$ GÜRCAN, Metin. Have Turkey-PKK clashes crossed fatal threshold?.Al-Monitor . [online].

16.05.2016. [cit. 2020-03-03]. Dostupné na: https://bit.ly/2WDtbht.

${ }^{55}$ MANDIRACI, ref. 45

56 GTD, ref. 39
} 
Binali Yıldırım onedlho oznámil ukončenie bojov na juhovýchode, pričom oznámil vládny plán na obnovu bojmi zničených miest. ${ }^{57}$

Kým spočiatku sa zdalo, že turecké operácie budú predstavovat' opät' najmä letecké bombardovanie, obmedzené defenzívne výpady lokálnych síl v reakcii na jednotlivé útoky ozbrojených zložiek PKK/KCK a kombinované operácie za účasti špeciálnych policajných jednotiek, armády a žandarmy kryté zo vzduchu bojovými helikoptérami, lietadlami F-16 a prieskumnými dronmi spolu s raziami voči skladom zbraní a konšpiračným bytom, nebolo tomu tak. Turecké bezpečnostné zložky sa $v$ prvom rade výraznejšie zamerali na zdroj prijmov PKK/KCK, ked’ podnikli rozsiahle akcie voči marihuanovým poliam nachádzajúcim sa najmä v provincii Diyarbakır. ${ }^{58}$ Zároveň sa objavili náznaky, že Turecko sa zameralo na likvidáciu vytypovaných významných postáv PKK/KCK, ked' sa najprv objavili (neskôr vyvrátené) správy o usmrtení významného velitel'a HPG Fehmana Hüseyina v Sýrii a neskôr bol špeciálnymi jednotkami zabitý Servet İnci, na ktorého bola vypísaná odmena 300000 tureckých lír. ${ }^{59}$ Nebolo by to prvýkrát, čo by Turecko zvolilo podobnú stratégiu, indície naznačujú, že turecká tajná služba MIT stála za zavraždením troch prominentných členov PKK/KCK v januári 2013 v Paríži. ${ }^{60}$

Výrazné zmeny $v$ postupe proti PKK/KCK prinieslo najmä obdobie po júlovom pokuse o prevrat. $\vee$ rámci vyhláseného výnimočného stavu, trvajúceho niekolko mesiacov, mal turecký režim vol'né ruky $\mathrm{k}$ rozšireniu a zintenzívneniu postupu voči elementom $v$ krajine, ktoré považoval za nepriatel'ské, vrátane PKK/KCK. Už v auguste prezident Erdoğan deklaroval, že Turecko nebude rozlišovat' medzi Gülenovým hnutím, ktorému je kladená zodpovednost' za prevrat, PKK/KCK alebo IS, ked'že všetky menované subjekty sú teroristickými organizáciami. ${ }^{61}$ Tento postoj potvrdil aj premiér Yıldırım, ked' začiatkom septembra odmietol akékolvek úvahy o obnovení mierových rozhovorov s PKK/KCK, a naopak, oznámil ofenzívnejší postup voči organizácii. ${ }^{62}$

Nová turecká stratégia predstavuje snahu o totálne vyhladenie PKK/KCK a jej odnoží vo vojenskej, politickej, socio-kultúrnej a ekonomickej sfére. ${ }^{63}$ Kým dovtedajší postup voči PKK/KCK zahŕňal predovšetkým statickú kontrolu územia a málo flexibilné rozsiahle operácie, nový rámec sa spolieha na najmodernejšiu techniku a dynamické operácie za účasti špeciálnych jednotiek, presného bombardovania $\mathrm{F}-16$, leteckej podpory nových bojových vrtulníkov T129 ATAK a nasadenia nielen prieskumných, ale aj bojových dronov ako Bayraktar TB2. Posilnené sú tiež dedinské stráže, ktoré prestali byt' len statickým nástrojom na ochranu vlastných usadlostí a boli nasadené v celom regióne juhovýchodu

\footnotetext{
${ }^{57}$ HÜRRIYET DAILY NEWS. Anti-PKK operations over, time for reconstruction: Turkish PM. [cit. 2020-03-03]. Dostupné na: https://bit.ly/39aMill.

58 DAILY SABAH. Fresh operations in s.eastern Turkey to destroy PKK's cannabis fields, group's largest source of income. [cit. 2020-03-03]. Dostupné na: https: / /bit.ly/3adtK5z.

59 DAILY SABAH. PKK terrorist on most wanted list killed in Ordu. [cit. 2020-03-03]. Dostupné na: https: / /bit.ly/2UtzPEk.

60 WHITE, Paul. The PKK: Coming down from the mountains. s. 112-114, Londýn: Zed books Ltd., 2015. ISBN: 1783600373.

${ }^{61}$ ANADOLU AGENCY. No difference between FETO, PKK, Daesh: Erdogan. [cit. 2020-03-03].

Dostupné na: https: //bit.ly/2JbzaSs.

${ }^{62}$ HÜRRIYET DAILY NEWS. No re-launch of PKK peace process but normalization with Syria, Egypt

on agenda: Turkish PM. [cit. 2020-03-03]. Dostupné na: https://bit.ly/3e39Taw.

63 WASILEWSKI, Karol. Turkey's New Anti-PKK Strategy: Consequences and Feasibility. PISM

Bulletin. [online]. 01. 12. 2016. [cit. 2020-03-03]. Dostupné na: https://bit.ly/3bOqqh1.
} 
Turecka. Ochranu miest by mali zabezpečovat' početne navýšené špeciálne jednotky polície a žandarmy rozmiestnené $v$ outpostoch. Zároveň bol do urbánnych zón implementovaný koncept dedinských stráží, ked' vznikla akási susedská stráž zodpovedajúca za bezpečnost' $v$ jednotlivých štvrtiach.

$V$ snahe o eliminovanie podpory PKK/KCK bolo zadržaných a obvinených z podpory terorizmu viacero poslancov HDP, vrátane oboch predsedov. Velké množstvo starostov a predstavitelov samosprávnych oblastí za strany HDP a DBP bolo zadržaných a nahradených vládnymi poverencami. Obvinenia $\vee$ prípade starostov zahŕňali finančnú, materiálnu a logistickú podporu pre PKK/KCK. Tiež bolo nariadené ukončenie vysielania viacerých kurdských staníc a rádií obvinených zo šírenia propagandy pre PKK/KCK a spustené vyšetrovanie podnikatelov, ktorí platili organizácii výpalné za ochranu. Prepúšt’anie postihlo vyše 11000 učitel'ov, u ktorých malo byt' údajne zistené prepojenie na PKK/KCK. ${ }^{64}$ Ďalším krokom tureckého režimu bolo zastavenie činnosti pre 190 mimovládnych organizácií zo začiatku novembra. ${ }^{65}$ Rozsah, v akom turecký režim zakročil, dosiahol až absurdné rozmery, a stal sa tak nielen snahou o elimináciu podpory vybraných elementov civilnej sféry pre PKK/KCK, ale zároveň prostriedkom $\mathrm{k}$ odstráneniu akejkolvek názorovej opozície voči AKP v kurdských aj tureckých kruhoch.

$\checkmark$ čase policajných operácií voči predstavitelom HDP bol $v$ Turecku navyše zablokovaný prístup na viacero sociálnych médií, ako Facebook, Twitter, YouTube, či komunikačné služby, ako WhatsApp a Skype. Napriek tomu, že Turecko bolo (a stále je) od celkovej porážky PKK/KCK ešte d’aleko, jednoznačne sa mu podarilo od ukončenia bojov v mestách prebrat' strategickú iniciatívu do svojich rúk. Tú si drží dodnes.

\section{ZÁVER: ZHRNUTIE A POSTREHY}

Vývoj konfliktu medzi Tureckom a PKK/KCK v sledovanom období názorne demonštruje, ako môžu Kilcullenove myšlienky o prechode povstaleckých organizácií z horského prostredia do urbánnych zón vyzerat' v praxi. Prípad PKK/KCK ale ukazuje, že to nemusia byt' len pobrežné vel'komestá, ktoré sa môžu stat' „bojiskom budúcnosti“, ale že sa môže jednat' tiež o relatívne menšie vnútrozemské sídla, nad ktorými sa povstalci môžu pokúsit prebrat' kontrolu. $V$ takom prípade však povstalecká organizácia do vel'kej miery prichádza o „ochranu“, ktorú vo velkomeste poskytuje splynutie s početným civilným obyvatel'stvom, ktoré následne komplikuje identifikáciu povstalcov a ich separáciu práve od civilistov. Zároveň sa ukazuje, že výhoda, ktorú poskytuje pobrežná urbánna zóna, v ktorej nie je možné nepriedušne uzavriet' povstaleckú organizáciu, môže byt' vel'mi efektívne nahradená polohou urbánnej zóny - bojiska na štátnej hranici. Tá rovnako neumožňuje úplnú izoláciu urbánnej zóny, v ktorej povstalecká organizácia operuje. Z tohto hladiska je poloha na hranici pre povstaleckú organizáciu ešte výhodnejšia ako poloha na pobreží, a to najmä v prípade ak je susediaca krajina v situácii, ked' nechce alebo nemôže povstaleckej organizácii bránit' $\vee$ prísune posíl do bojovej zóny, resp. nechce, alebo nie je v situácii umožňujúcej kooperáciu a koordináciu s krajinou a jej ozbrojenými zložkami vedúcimi boj proti povstaleckej organizácii. $V$ rámci tejto štúdie

${ }^{64}$ AL JAZEERA. Turkey suspends 11,000 teachers for suspected PKK links. [cit. 2020-03-03].

Dostupné na: https: / /bit.ly/2J6qLjr.

${ }^{65}$ REUTERS. Turkey halts activities of 370 groups as purge widens. [cit. 2020-03-03]. Dostupné na: https://reut.rs/33HgkfJ. 
takúto situáciu predstavoval Nusaybin, ležiaci na turecko-sýrskej hranici, kde boli ozbrojenci PKK/KCK schopní odolávat' tureckým bezpečnostným zložkám najdlhšie, predovšetkým vd'aka možnosti prisúvat' do mesta posily cez sýrske územie.

\section{Prevencia, príprava a využitie momentu}

Pri pohlade na priebeh povstania PKK/KCK v rokoch 2015-2016 je možné vyvodit' niekol'ko záverov. V prvom rade sa jedná o ukážkový príklad toho, ako tradične rurálna guerrillová organizácie dokáže vel'mi jednoducho preniest' boje do urbánnych zón, najmä ak dostane dostatok času a priestoru na budovanie svojej materiálnej a l'udskej základne $v$ mestách. V tomto konkrétnom prípade je tiež nutné zdôraznit', že dlhoročný boj Turecka s PKK/KCK zameraný takmer výhradne na snahu o zlomenie odporu hrubou silou výrazne prispel k nárastu podpory PKK/KCK medzi miestnou kurdskou mládežou, ktorá v predchádzajúcich bojoch prišla o niektorého z rodinných príslušníkov, alebo pocitovala krivdu voči tureckému štátu vd’aka jeho represívnemu postupu v otázke kurdských politických práv. Výrazný mobilizačný prvok sa objavil tiež v podobe prebiehajúcich volieb a najmä vývoja v Sýrii, ktorý predstavoval zásadnú hybnú silu najmä v úvode bojov. PKK/KCK spočiatku zareagovala na tieto trendy ovel'a aktívnejšie a využila nespokojnost' kurdskej populácie $v$ Turecku vo svoj prospech.

Z vyššie uvedeného je možné vyvodit' tieto postrehy:

- Schopnost' tradičnej rurálnej povstaleckej organizácie preniest' boj do urbánnych zón môže byt' prekvapivo rýchla, najmä ak má dostatok času a priestoru na budovanie podporných sietí.

- V oblastiach, kde pôsobia povstalecké organizácie dlhodobo, je dôležité držat' ich pod neustálym tlakom a neumožnit' im nerušenú výstavbu podporných sietí.

- Sústredenie sa výhradne na dlhodobé používanie hrubej sily v boji proti povstaleckej organizácii sa z dlhodobého hladiska môže ukázat' ako kontraproduktívne a môže spôsobit' práve nárast podpory povstaleckej organizácie medzi lokálnym obyvatel'stvom, najmä ak priamo znáša negatívne dopady štátnych opatrení.

- Podcenenie, prípadne nedostatočná reakcia na ozbrojenú aktivitu povstaleckej organizácie môže spôsobit' zásadné problémy pri následných snahách o potlačenie odporu.

- V rámci preventívnych opatrení je nutné udržiavat' dostatočnú prítomnost' bezpečnostných zložiek v oblastiach, ktoré sú považované za rizikové a predíst' tak možnosti vytvorenia plošných centier odporu.

\section{Priebeh bojov}

PKK/KCK bola na jednej strane schopná podchytit' dynamiku vedúcu k otvorenému konfliktu ovel'a efektívnejšie, než turecká strana, avšak z dlhodobého hladiska sa nechala týmto živelným vývojom konfliktu zatiahnut' do priamej konfrontácie s ovela lepšie vyzbrojeným oponentom. Kým teda v úvodnej a prípadne strednej fáze bojov predstavovali mestské zóny výhodu pre lahšie vyzbrojené zložky PKK/KCK, ktoré dokázali odrážat' a spôsobovat' straty tureckým ozbrojeným zložkám, prísun tureckej t’ažkej 
techniky a obklúčenie resp. izolácia vyhlásených autonómnych zón tureckými bezpečnostnými zložkami v zásade znamenala pre PKK/KCK neodvratnú porážku.

Je tiež nutné povedat', že turecká strana v prvopočiatku podcenila potenciál, ktorým PKK/KCK disponovala priamo v mestách. Spočiatku nasadené policajné jednotky sa ukázali ako nedostatočné, a to aj proti relatívne slabo vyzbrojenej kurdskej mládeži. Napriek prísunu armády, kombinovaných tímov špeciálnych jednotiek a t’ažkej techniky, tureckej strane trvalo niekol'ko mesiacov, kým bola schopná vyčistit' posledné ohniská odporu v mestách ako Nusaybin. Práve Nusaybin, ktorý sa nachádza priamo na tureckosýrskej hranici, a kde PKK/KCK dokázala odolávat' najdlhšie, ukazuje dôležitost' akú má pri potláčaní odporu $\vee$ mestách izolácia oblasti odporu od okolitého sveta. Napriek absolútnej prevahe $v$ počte a výzbroji nedokázali turecké jednotky zlomit' odpor PKK/KCK po niekol'ko mesiacov. Ozbrojenci PKK/KCK ukázali schopnost' vel'mi rýchlo využit' schopnosti získané $v$ Sýrii $v$ boji proti IS a efektívne tak eliminovat' prevahu tureckých jednotiek. Počas obliehania mestských zón sa objavilo špecifikum v podobe zákazov vychádzania alebo odsunu väčšiny civilného obyvatel'stva z obliehaných oblastí. Turecká strana týmto krokom jednak prispela k zníženiu civilných strát a zároveň si otvorila priestor na nasadenie t'ažkej obrnenej techniky. Napriek tomu je ale možné postup tureckej strany podrobit' kritike, ked' si práve nasadenie masívnej hrubej sily $v$ mestskej zástavbe vyžiadalo civilné obete. Celkový turecký postup v sledovanom sa vyznačoval plošným postupom voči PKK/KCK, ked' súbežne prebiehali ako operácie v rurálnych oblastiach, tak operácie $v$ urbánnych zónach.

Z vyššie uvedeného je možné vyvodit':

- Mestské prostredie predstavuje ideálny priestor pre obranu, ked' do značnej miery eliminuje výhody početnejšieho, lepšie vycvičeného a lepšie vyzbrojeného protivníka. Nepoužitel'nou sa stáva do značnej miery ako letecká podpora, tak t’ažká pozemná bojová technika.

- Obklúčenie a izolácia povstalcov od možnej externej podpory predstavuje klúčový prvok pri postupe voči povstalcom v meste.

- Nie je možné podceňovat' schopnosti povstaleckých organizácií učit' sa. Tradičné metódy a prostredie boja môžu povstalecké jednotky vel'mi jednoducho doplnit' o inovatívne prvky (terorizmus, mestskú guerillu), najmä ak majú možnost' praktického prístupu k získavaniu takýchto poznatkov, hoc aj na území iných krajín. Dôležité je teda sledovat' dlhodobo, od koho a čo sa môže povstalecká organizácia učit'.

- Čo najjednoznačnejšie oddelenie civilného obyvatel'stva a povstalcov, napr. v podobe odsunu civilnej populácie z bojovej zóny ulahčuje priebeh bojových operácií.

- V prípade, že to zdroje umožňujú, je dôležité udržiavat' plošný tlak na povstalcov a nedovolit' im koncentrovat' sily na jedno miesto alebo oblast'. Ofenzívne operácie je nutné kombinovat' s plošnou kontrolou už vyčisteného územia, pričom urbánne zóny je vhodné chránit' formou viacerými vrstvami obrany, tj. zabezpečit' nielen samotnú urbánnu zónu ale aj prístupy knej, čo skomplikuje pohyb povstalcov nielen v samotnom meste ale aj prípadné snahy o vstup do neho. 


\section{Po ukončení bojov}

Turecko po porážke PKK/KCK v mestách jednoznačne prevzalo bojovú iniciatívu na svoju stranu. Komplexný postup voči PKK/KCK sa zameral na všetky aspekty existencie povstaleckej organizácie, tj. ako na vojenskú, tak politickú, socio-kultúrnu a ekonomickú sféru. PKK/KCK sa snažila zareagovat' zmenou taktiky, ked' YPS prešli od tzv. konečnej formy mestskej guerilly (dynamický, organizovaný boj, prepady zo zálohy atd'.) k jej klasickejšej forme v podobe sporadických bodových útokov voči predstavitelom štátu či tureckým bezpečnostným zložkám, avšak ukázalo sa, že jednak značne vyčerpala svoje možnosti v priamom boji počas predchádzajúcich mesiacov a taktiež, že nedokázala čelit' tureckému postupu na všetkých frontoch. Po taktickej stránke sa v mestách na juhovýchode Turecko sústredilo na zabezpečenie oblasti prostredníctvom zvýšenej stálej prítomnosti bezpečnostných zložiek doplnených o miestne milície platené štátom. Zároveň vybojovanú prevahu využila na d’alšie sprísnenie represívnych opatrení, čo sa v krátkodobom horizonte ukazuje ako efektívne, avšak prináša riziká spojené s d’alším nárastom nespokojnosti lokálnej kurdskej populácie v dlhodobom horizonte.

\section{Z toho vyplýva:}

- Počas bojových operácií aj po ich ukončení je nutné presadzovat' komplexný postup zameriavajúci sa nielen na vojenské, ale aj politické, ekonomické a ludské zdroje povstalcov a oslabenie ich základne podporovatel'ov.

- V prostredí, kde povstalecká organizácia nemá absolútnu podporu obyvatel'stva, môže priniest' v krátkodobom horizonte výsledky výhradne (alebo takmer výhradne) represívny postup.

- Vhodné je ale okrem represívnych opatrení ponúknut' lokálnej populácii tiež alternatívne pozitívne stimuly, ktoré dokážu z dlhodobého hladiska oslabit' vplyv a podporu povstaleckej organizácie medzi civilistami. To zahŕňa sociálne a ekonomické benefity a najmä poskytnutie pocitu bezpečia.

- Zapojenie lojálneho lokálneho obyvatel'stva do spolupráce proti povstaleckej organizácii môže priniest' výhody v podobe znalosti prostredia a informácií, avšak kladie vysoké nároky na preverovanie si spolupracovníkov. 